\title{
Alternative model of intense rainfall equation obtained from daily rainfall disaggregation
}

\section{Modelo alternativo de equação de chuvas intensas obtida a partir da desagregação da chuva diária}

\author{
Álvaro José Back ${ }^{1}$ \\ ${ }^{1}$ Empresa de Pesquisa Agropecuária e Extensão Rural de Santa Catarina, Urussanga, SC, Brasil \\ E-mail: ajb@epagri.sc.gov.br (AJB)
}

Received: April 01, 2019 - Revised: August 19, 2019 - Accepted October 11, 2019

\begin{abstract}
The objective of this work was to propose an alternative model of IDF equation based on the disaggregation of daily rainfall. Data from the rainfall gauge station code 02649018 of the Brazilian National Water Agency from the period 1968 to 2011 were used. Several extreme event probability distributions were adjusted. Rainfall intensity with a return period of 2 to 100 years and durations of 5 to 1440 minutes were estimated using the relationships between rainfall for different durations. The four coefficients of the traditionally used IDF equation were adjusted, obtaining a sum of squares of deviations equal to 695.1 (mm.h $\left.\mathrm{h}^{-1}\right)^{2}$ and standard error of estimation equal to $2.69 \mathrm{~mm} \cdot \mathrm{h}^{-1}$. For the model of the intense rainfall equation proposed, that relates the rain intensity and duration with the maximum daily rainfall, the sum of squares of the deviations was $33.6\left(\mathrm{~mm} \cdot \mathrm{h}^{-1}\right)^{2}$ and the standard estimated error was $0.59 \mathrm{~mm} \cdot \mathrm{h}^{-1}$. Including the return period in the model, we obtained squares of the deviations of $129.4\left(\mathrm{~mm} \cdot \mathrm{h}^{-1}\right)^{2}$, with a standard error of estimation of $1.16 \mathrm{~mm} \cdot \mathrm{h}^{-1}$. The models proposed have, besides better estimation accuracy, the advantages of facilitating the updating only by updating the maximum daily precipitation and sub serve the spatial representation.
\end{abstract}

Keywords: Intense rains; IDF equation; Precipitation disaggregation.

\section{RESUMO}

O objetivo foi a proposição de um modelo alternativo de equação Intensidade-Duração-Frequência de chuvas intensas com base na desagregação da chuva diária. Foram utilizados dados pluviométricos da estação pertencente a Agência Nacional de Águas (código 02649018) do período de 1968 a 2011. Foram ajustadas diversas distribuições probabilísticas para séries de eventos extremos. Com as relações entre chuvas de diferentes durações foram estimadas as intensidade de chuva com período de retorno de 2 a 100 anos e durações de 5 a 1440 minutos. Foram ajustados os coeficientes da equação IDF tradicionalmente usada, obtendo soma de quadrados de desvios de $695,1\left(\mathrm{~mm} \mathrm{~h}^{-1}\right)^{2}$ e erro padrão de estimativa de 2,69 $\mathrm{mm} \mathrm{h}^{-1}$. Para o modelo de equação de chuvas intensas proposto, que relaciona a intensidade e a duração da chuva com a chuva máxima diária, obteve-se a soma de quadrados dos desvios de $33,6\left(\mathrm{~mm} \mathrm{~h}^{-1}\right)^{2}$ e erro padrão de estimativa de $0,59 \mathrm{~mm} \mathrm{~h}^{-1}$. Quando incluído no modelo o período de retorno, obteve-se a soma dos quadrados dos desvios de 129,4 $\left(\mathrm{mm} \mathrm{h}^{-1}\right)^{2}$, com erro padrão de estimativa de $1,16 \mathrm{~mm} \mathrm{~h}^{-1}$. O modelo proposto além de melhor precisão de estimativa, tem as vantagens de facilitar a atualização apenas pela alteração da chuva máxima diária e auxiliar a representação espacial.

Palavras-chave: Chuvas intensas; Equação IDF; Desagregação da chuva. 


\section{INTRODUCTION}

The knowledge of the heavy rainfall characteristics is important for the design of rainwater drainage structures, such as urban drainage works, and erosion control structures. For a complete characterization of the rainfall, the rain's intensity or height, duration and frequency has to be determined (Pérez-Zanón et al., 2016; Pereira et al., 2017; Coelho Filho et al., 2017). The relations of these quantities can be expressed with the intensity rain equations or the IDF equations.

The IDF equations are widely used in several hydrological procedures and are of great importance because they allow the use of computational routines in the hydrological calculations that involve the design rainfall. Silveira (2016) used the IDF equation to determine the hietogram of the Chicago method. Several methodologies have been developed for designing terraces and soil conservation works where the runoff is calculated using the IDF equations (Griebeler et al., 2005; Fietz et al., 2011; Miranda et al., 2012; Xavier et al., 2014). The use of the IDF equation is also frequent in software or spreadsheets for designing urban drainage structures. Damé et al. (2008) emphasize the importance of IDF equations as input data in models that make rain-flow transformation.

The determination of the IDF ratios for short-term rainfall requires long series of rainfall data and requires a great deal of effort in the tabulation, processing, analysis and interpretation of large numbers of pluviograms data (Garcia et al., 2011; Campos et al., 2014; Bielenki Júnior et al., 2016).

The pluviographic series, besides a smaller number, have generally shorter periods and with more failures than the pluviometric series. Sobrinho et al. (2014) highlight the reduced number of pluviographic information and deficiencies in the monitoring network in the semi-arid region of Brazil, as well as in many regions of the world. The World Meteorological Organization (WMO) recommends the use of series with at least 30 years of data in hydrological studies (Oliveira et al., 2008; Silva et al., 2012; Braga et al., 2018). Rodrigues et al. (2008) also emphasize the importance of the size of the data series on the accuracy of the results of the IDF equation.

If there is no available equation for a specific area, the established one for the closest location may be used provided it has similar climatic conditions (Damé et al., 2008). Also, parameters determined for locations close to the area of interest may be interpolated (Mello et al., 2003; Pruski et al., 2006; Cecílio et al., 2009).

The lack of long pluviographic data contrasts with the relative abundance of daily rainfall data series (Oliveira et al., 2005). Thus, the use of daily rainfall disaggregation techniques in short-term rainfall has been very common, and the IDF equation obtained from these data has been used (Svensson et al., 2007; Garcia et al., 2011; Aragão et al., 2013, Rangel \& Hartwig, 2017). The method of disaggregation of the daily rainfall has as assumption that there are approximately constant relations between the precipitated amount in one day and precipitated amount in shorter periods (Back, 2013).

For daily rainfall disaggregation, different methodologies can be used, among which the isozones method (Santos, 2015; Basso et al., 2016), the method of relations between durations and the method of Bell (Silva \& Oliveira, 2017). In Brazil, the use of the disaggregation's coefficients presented by CETESB (Companhia de Tecnologia de Saneamento Ambiental, 1986) (Aragão et al., 2013; Pereira et al., 2017) is widely diffused. According to Tucci (2013), this method is based on two characteristics observed in the intense rainfall curves of several places in the world: (1) probability curves of different durations tend to remain parallel to each other; (2) for different sites, there is great similarity in the relationships between maximum average rainfall of different durations.

Several studies comparing methodologies to obtain an IDF equation by rainfall disaggregation showed that the method using the coefficients of CETESB was the one that best represented the maximum rainfall intensities (Robaina, 1996; Damé et al., 2008; Garcia et al., 2011; Caleira et al., 2015).

Helfer et al. (2017) point out that most of the adjustments of these equations are performed using only one equation. However, in order to obtain better precision in rainfall intensity estimates, some authors establish multiple IDF curves, with two or more distinct equations, valid for certain rainfall duration ranges. Martins et al. (2017) justify this procedure by the distinct behavior of the different types of rains. Rainfall of shorter durations has the convection effect more frequent, whereas rains with longer durations can have combined effects of orography and of fronts and thus present different behavior. Pompeu (1992), Bielenki Júnior et al. (2016) and Martins et al. (2017) used the $60 \mathrm{~min}$ limit for the validity of the equations. Back et al. (2011) used the limit with 120 minutes to adjust the equations of intense rainfall with rainfall data from Santa Catarina. Helfer et al. (2017) point out that although the multiple IDF equations show a better fit to the observed rainfall data than the single IDF equation, the magnitude of the discontinuity at the transition point between the equations can cause changes in the values of the flow rate peak and the hydrographs volume.

The IDF relations need constant updating (Berne et al., 2004; Aragão et al., 2013, Silva \& Araújo, 2013). Braga et al. (2018) points out that there is a need for periodic review of the IDF equations at least once every decade and also emphasizes that more recent historical precipitation series should be used. The procedure of adjusting the coefficients of the IDF equation is laborious and requires specific statistical routines. The use of more than one equation, in addition to raising the degree of difficulty in adjusting the rainfall equations, may cause discontinuity in the IDF relation.

Most of the existing IDF curves were elaborated based on the theory of extreme stationary values, however, the hypothesis of intensification of extreme rainfall events and non-stationarity of the historical series may compromise the use of these IDF equations. Some studies are being carried out to incorporate future climate changes into IDF relations (Liew et al., 2014; Cheng \& Aghakouchak, 2014; Costa et al., 2019). Srivastav et al. (2014) show an increasing trend of extreme precipitation compared to the IDF adjusted to the most recent data available. The increase is in a range of $4.5 \%$ for a lower emissions scenario to about $31 \%$ for a scenario with higher emissions and longer return periods. Costa et al. (2019) demonstrate a method to incorporate changes in future climate variability.

However, historical series of short-term precipitation are relatively short and scarce, making it difficult to assess climatic trends. Thus, in the vast majority of cases the IDF equations are used assuming the 


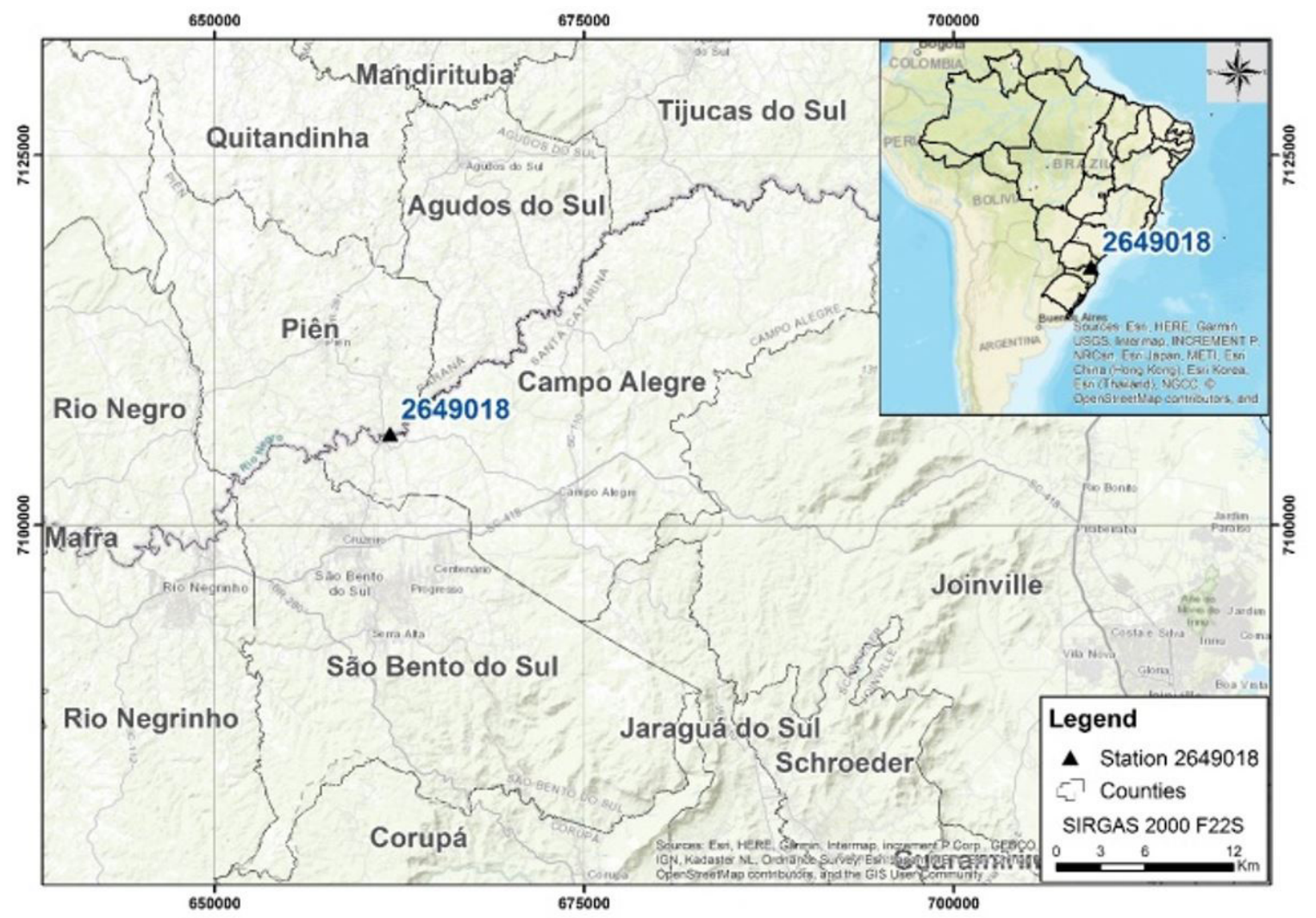

Figure 1. Location of rainfall station.

stationarity hypothesis. Srivastav et al. (2016) emphasize that climate change will likely result in an increase in the intensity and frequency of extreme precipitation events in most regions in the future. As a result, IDF values will optimally need to be updated more frequently than in the past and climate change scenarios might eventually be drawn upon in order to inform IDF calculations.

In the method of relations between durations the adjustment of the IDF equation can be divided into three stages. In the first stage, a probability distribution is adjusted to series of annual maximum daily rainfall, and with this distribution the rainfall is estimated with a duration of 1 day and a return period usually between 2 and 100 years. In the second stage, the disaggregation coefficients are used to estimate rain intensities (or heights) with duration of 5 to 1440 minutes. The third stage is to adjust the coefficients of the IDF equation. In this work we intend to propose and evaluate a simpler method to represent the IDF equation from the disaggregation of daily rainfall.

\section{MATERIAL AND METHODS}

The historical series of daily precipitation from the rainfall station of the Hydrological Network of the Brazilian National Water Agency was used. The station code 02649018 is located in the municipality of Piên, state of Paraná, Latitude 2609 '16.92”'S, Longitude $49^{\circ} 22$ '50.16' W' (Figure 1).

In the study, we used a series of annual maximums for the rainfall from 1968 to 2011, without fail. The stationarity of the series was confirmed by the Mann-Kendall test ( $p=0.5683$ ) (Yue et al., 2002).

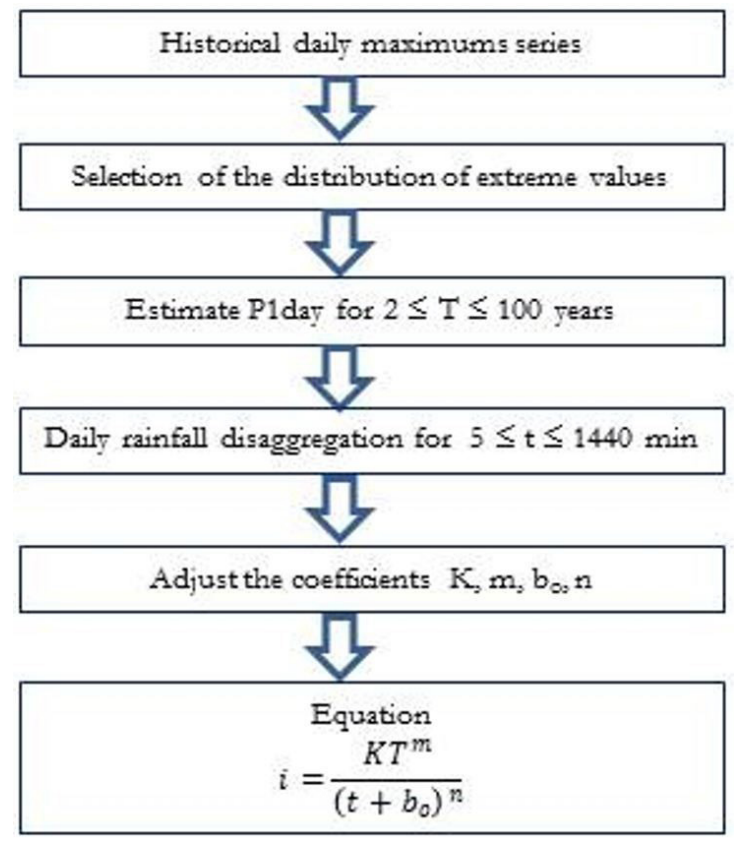

Figure 2. Schematization of the algorithm that generates the IDF equations by daily rainfall disaggregation.

The traditional method of adjusting the rainfall equation by means of the daily rainfall disaggregation is shown in Figure 2.

The Log-Normal with 2 parameters (LN2), the Log-Normal with 3 parameters (LN3), Pearson type III (PIII), Log-Pearson 
type III (LPIII), distribution of Type I Extremes or distribution of Gumbel (Gb) and the Generalized Distribution of Extreme Values (GEV) probability distributions were adjusted. These adjustments were made as described in Kite (1977) and Naghettini \& Pinto (2007). The maximum likelihood method (ML) (Naghettini \& Pinto, 2007), L-Moment Method (MML) (Hosking \& Wallis, 1997) was used to determine the parameters of each distribution. For the Gumbel distribution, the Chow (Ch) method was used to estimate the parameters (Back, 2013). To evaluate the adherence and distribution selection the Kolmogorov-Smirnov (KS) test the Anderson-Darling (AD) test at the significance level of 5\% were used (Naghettini \& Pinto, 2007).

The values of maximum rainfall with duration of one day and period of return of 2, 5, 10, 15, 20, 25, 50 and 100 years were estimated. With the coefficients in Table 1 , the mean maximum rainfall intensity were obtained for the durations of $5,10,15,20,25,30,60,360,80,600,720$ and 1440 minutes.

The traditionally used IDF equation is given by:

$$
i=\frac{K T^{m}}{\left(t+b_{0}\right)^{n}}
$$

Where: $\mathrm{i}$ is the mean maximum rainfall intensity $\left(\mathrm{mm} \mathrm{h}^{-1}\right) ; \mathrm{K}, \mathrm{m}, \mathrm{b}_{\mathrm{o}}, \mathrm{n}$ are the coefficients of the equation to be adjusted; $T$ is the return period (years); $t$ is the rainfall duration (minutes).

For the adjustment of the equation we used the minimization function S given (Back, 2013) by:

$\mathrm{S}=\sum_{\mathrm{j}=1}^{\mathrm{n}}\left(\mathrm{G}_{\mathrm{T}}^{\mathrm{t}}-\mathrm{I}_{\mathrm{T}}^{\mathrm{t}}\right)^{2}$

Where: $\mathrm{S}$ is the sum of the squared deviations; $\mathrm{t}$ is the rain duration (min); $T$ is the return period (years); $G$ is the rainfall intensity estimated by the probability distribution; $I$ is the rainfall intensity estimated by the IDF equation.

A function to estimate the height of the rain (h) with duration of $t$ minutes from the maximum rain of 1 day (P1day) was fitted, using the coefficients of disaggregation, as given by:

$\mathrm{h}=\left(\frac{\mathrm{t}}{\mathrm{a}+\mathrm{bt}^{\mathrm{c}}}\right) \mathrm{P}_{\text {lday }}$

Where: $\mathrm{h}$ is the height of the rain $(\mathrm{mm})$; $\mathrm{t}$ is the rain duration (min); $\mathrm{P}_{1 \mathrm{day}}$ is the maximum rainfall lasting 1 day ( $\left.\mathrm{mm}\right) ; \mathrm{a}, \mathrm{b}, \mathrm{c}$ are coefficients to be adjusted with the disaggregation coefficients.

The rainfall intensity can be obtained by the expression:

$i=\left(\frac{60}{a+b t^{c}}\right) P_{\text {lday }}$

Where $\mathrm{i}$ is rain intensity $\left(\mathrm{mm} \mathrm{h}^{-1}\right)$.

\section{RESULTS AND DISCUSSION}

Table 2 shows the adjusted parameters for each distribution and the respective values of the adhesion tests. The KS and AD tests did not reject any distribution, so all can be used to estimate the maximum daily rainfall. To select the best distribution the criterion of the lowest $\mathrm{D}_{\max }$ value or the lowest value of the $\mathrm{AD}$ statistic can be used. With these criteria the Log-Pearson type III
Table 1. Rainfall disaggregation coefficients.

\begin{tabular}{cc}
\hline $\begin{array}{c}\text { Relationships between } \\
\text { rainfall durations }\end{array}$ & Coefficients \\
\hline $24 \mathrm{~h} / 1 \mathrm{day}$ & 1.14 \\
$12 \mathrm{~h} / 24 \mathrm{~h}$ & 0.85 \\
$10 \mathrm{~h} / 24 \mathrm{~h}$ & 0.82 \\
$8 \mathrm{~h} / 24 \mathrm{~h}$ & 0.78 \\
$6 \mathrm{~h} / 24 \mathrm{~h}$ & 0.72 \\
$1 \mathrm{~h} / 24 \mathrm{~h}$ & 0.42 \\
$30 \mathrm{~min} / \mathrm{h}$ & 0.74 \\
$25 \mathrm{~min} / 30 \mathrm{~min}$ & 0.91 \\
$20 \mathrm{~min} / 30 \mathrm{~min}$ & 0.81 \\
$15 \mathrm{~min} / 30 \mathrm{~min}$ & 0.70 \\
$10 \mathrm{~min} / 30 \mathrm{~min}$ & 0.54 \\
$5 \mathrm{~min} / 30 \mathrm{~min}$ & 0.34 \\
\hline Source: CETESB (Companhia de Tecnologia de Saneamento Ambiental, 1986).
\end{tabular}

Table 2. Parameters of the distributions adjusted with the respective values of the Kolmogorov-Smirnov (Dmax) and Anderson-Darling (AD) adhesion tests).

\begin{tabular}{lcccccc}
\hline \multirow{2}{*}{ Distribution $^{1}$} & \multicolumn{3}{c}{ Parameters $^{2}$} & & \multicolumn{2}{c}{ Adhesion test $^{3}$} \\
\cline { 2 - 3 } \cline { 6 - 7 } & $\boldsymbol{\alpha}$ & $\boldsymbol{\beta}$ & $\mathbf{k}$ & & $\mathbf{D}_{\max }$ & $\mathbf{A D}$ \\
\hline LN2-MM & 4.364 & 0.268 & & 0.0877 & 0.4876 \\
LN2-ML & 4.365 & 0.262 & & 0.0942 & 0.6308 \\
LN2-MML & 4.362 & 0.275 & & 0.0800 & 0.5379 \\
LN3-MM & 4.5282 & 0.2308 & 13.680 & & 0.0851 & 0.4995 \\
LN3-ML & 3.6886 & 0.5119 & 36.224 & & 0.0873 & 0.4742 \\
LN3-MML & 4.1559 & 0.333 & 13.968 & & 0.0809 & 0.4362 \\
PIII-MM & 11.274 & 4.139 & 34.751 & & 0.0828 & 0.4718 \\
PIII-ML & 8.362 & 6.334 & 28.56 & & 0.0828 & 0.5362 \\
PIII-MML & 11.274 & 4.139 & 34.751 & & 0.0770 & 0.3963 \\
LPIII-MM & 0.032 & 70.730 & 2.133 & & 0.0843 & 0.4508 \\
LPIII-ML & 0.030 & 73.276 & 2.133 & & 0.0743 & 0.4508 \\
LPIII-MML & 0.174 & 3.992 & 3.727 & & 0.0628 & 0.3205 \\
Gb-MM & 17.347 & 71.403 & & 0.0990 & 0.5560 \\
Gb-ML & 17.440 & 71.203 & & 0.0966 & 0.5584 \\
Gb-MML & 18.116 & 70.954 & & 0.0839 & 0.4542 \\
Gb-Ch & 19.348 & 70.856 & & 0.0715 & 0.4233 \\
GEV-MM & 19.088 & 71.839 & 0.082 & & 0.0857 & 0.4880 \\
GEV-MML & 18.327 & 71.065 & 0.013 & & 0.0832 & 0.4511 \\
\hline
\end{tabular}

${ }^{1}$ Log-Normal with two parameters (LN2); Log-Normal with three parameters (LN3); Pearson type III (PIII); Log Pearson type III (LPIII) Gumbel distribution (Gb); Generalizes Distribution of Extreme Values (GEV); Method of moments (MM); Maximum likelihood method of (ML); Method of L-moments (MML);Chow method (Ch); ${ }^{2} \alpha$ is the scale parameter; $\beta$ is the form parameter; $\mathrm{k}$ is the location parameters; ${ }^{3} \mathrm{D}_{\max }$ is the Kolmogorov-Smirnov value test; $\mathrm{AD}$ is de Anderson-Darling value test.

distribution with parameters adjusted by the L-moments likelihood method (LPIII-MML) was the selected distribution.

The maximum daily rainfall values for return periods of 2 to 100 years were estimated with the different distributions are shown in Table 3. Taking as reference the estimated values with the LPIII-MML distribution with the return period of 10 years, it is observed that the LPIII-MV distribution presented underestimates of $5.9 \%$. For all the others the differences were less than $5 \%$. For the 100-year return period, the largest difference was $11.9 \%$, obtained with the LN3-ML distribution. These results show that, 
for this data series, all distributions tested could be used to estimate the maximum daily rainfall.

Several papers showed that the annual maximum rainfall series fit well for the Gumbel distribution (Back et al., 2011), and often this distribution is used without performing the adhesion test (Oliveira et al., 2005; Ottero et al., 2018), or without checking for another distribution that fits best. The generalized distribution of extreme values (GEV) has been widely accepted for the discretion of natural maximum events. Studies on the subject show that the GEV distribution adjusts values closer to reality when there is a need to extrapolate the sample data to large periods of returns (Quadros et al., 2011).

Applying the rainfall disaggregation coefficients (Table 1), the average maximum rainfall intensities for different durations and return period are obtained (Table 4). With this data we adjusted the rainfall equation, given by expression 5 , where the sum of the squares of the deviation (objective function S) was $695.1\left(\mathrm{~mm} \mathrm{~h}^{-1}\right)^{2}$, with the standard error of estimate (Ep) of $2.69 \mathrm{~mm} \mathrm{~h}^{-1}$. Braga et al. (2018) adjusting IDF equations to 32 stations in the state of Rio de Janeiro obtained a standard error of estimation ranging from 2.29 to $5.38 \mathrm{~mm} \mathrm{~h}^{-1}$.

$i=\frac{778.68 T^{0.151}}{(t+9.78)^{0.724}}$

The squares of the deviations between the intensities obtained with the disaggregation (Table 4) and the intensities estimated by the intense rainfall equations are show in Table 5 . It can be seen that the greatest deviations occur at the extremes of the return period (both lower and higher values) and also for the shortest durations. This behavior is due to the objective function used in the adjustment of the equation, and has already being observed in other studies on equation adjustment of heavy rains (Back et al., 2011; Almeida et al., 2015). Since the deviations are generally greater for the duration of 5 minutes some authors

Table 3. Values of maximum rainfall with durations of 1 day estimated by the probability distributions.

\begin{tabular}{lcccccccc}
\hline \multicolumn{1}{c}{ Probability } & \multicolumn{7}{c}{ Return period (years) } \\
\hline \multicolumn{1}{c}{ Distribution ${ }^{1}$} & $\mathbf{2}$ & $\mathbf{5}$ & $\mathbf{1 0}$ & $\mathbf{1 5}$ & $\mathbf{2 0}$ & $\mathbf{2 5}$ & $\mathbf{5 0}$ \\
\hline LN2-MM & 78.6 & 98.5 & 110.8 & 117.5 & 122.1 & 125.6 & 136.2 & 146.6 \\
LN2-ML & 78.6 & 98.1 & 110.0 & 116.5 & 121.0 & 124.4 & 134.7 & 144.7 \\
LN2-MML & 78.4 & 98.8 & 111.5 & 118.5 & 123.3 & 126.9 & 137.9 & 148.7 \\
LN3-MM & 78.9 & 98.8 & 110.8 & 117.3 & 121.7 & 125.0 & 135.1 & 144.8 \\
LN3-ML & 76.2 & 97.7 & 113.3 & 122.4 & 129.0 & 134.2 & 150.6 & 167.7 \\
LN3-MML & 77.8 & 98.4 & 111.8 & 119.2 & 124.3 & 128.3 & 140.4 & 152.4 \\
PIII-MM & 77.8 & 98.8 & 112.0 & 119.3 & 124.3 & 128.1 & 139.6 & 150.8 \\
PIII-ML & 78.8 & 97.9 & 109.6 & 115.9 & 120.2 & 123.4 & 133.1 & 142.4 \\
PIII-MML & 77.8 & 98.8 & 112 & 119.3 & 124.3 & 128.1 & 139.6 & 150.7 \\
LPIII-MM & 81.0 & 101.7 & 114.7 & 121.9 & 126.7 & 130.5 & 141.9 & 153.0 \\
LPIII-ML & 75.9 & 94.3 & 105.8 & 112.0 & 116.3 & 119.6 & 129.5 & 139.2 \\
LPIII-MML & 78.4 & 98.8 & 111.6 & 118.7 & 123.6 & 127.3 & 138.7 & 149.9 \\
Gb-MM & 77.8 & 97.4 & 110.4 & 117.8 & 122.9 & 126.9 & 139.1 & 151.2 \\
Gb-ML & 77.5 & 97.1 & 110.0 & 117.3 & 122.4 & 126.3 & 138.5 & 150.5 \\
Gb-MML & 77.6 & 98.1 & 111.7 & 119.4 & 124.8 & 128.9 & 141.6 & 154.3 \\
Gb-Ch & 77.9 & 99.9 & 114.4 & 122.6 & 128.3 & 132.7 & 146.3 & 159.9 \\
GEV -MM & 78.7 & 98.8 & 111.1 & 117.7 & 122.2 & 125.5 & 135.6 & 145.0 \\
GEV -MML & 77.8 & 98.3 & 111.7 & 119.2 & 124.5 & 128.5 & 140.8 & 152.9 \\
\hline
\end{tabular}

${ }^{1}$ Log-Normal with two parameters (LN2); Log-Normal with three parameters (LN3); Pearson type III (PIII);Log Pearson type III (LPIII) Gumbel distribution (Gb); Generalizes Distribution of Extreme Values (GEV); Method of moments (MM); Maximum likelihood method of (ML); Method of L-moments (MML);Chow method (Ch).

Table 4. Rainfall intensity $\left(\mathrm{mm} \mathrm{h}^{-1}\right)$ obtained by the rainfall disaggregation with the Cetesb coefficients.

\begin{tabular}{crrrrrrrc}
\hline \multirow{2}{*}{$\begin{array}{c}\text { Duration } \\
\mathbf{t}(\mathbf{m i n})\end{array}$} & \multicolumn{7}{c}{ Return period (years) } \\
\cline { 2 - 8 } & $\mathbf{2}$ & $\mathbf{5}$ & $\mathbf{1 0}$ & $\mathbf{1 5}$ & $\mathbf{2 0}$ & $\mathbf{2 5}$ & $\mathbf{5 0}$ & $\mathbf{1 0 0}$ \\
\hline 5 & 113.3 & 142.8 & 161.3 & 171.6 & 178.7 & 184.0 & 200.5 & 216.7 \\
10 & 90.0 & 113.4 & 128.1 & 136.3 & 141.9 & 146.1 & 159.2 & 172.1 \\
15 & 77.8 & 98.0 & 110.7 & 117.8 & 122.6 & 126.3 & 137.6 & 148.7 \\
20 & 67.5 & 85.1 & 96.1 & 102.2 & 106.4 & 109.6 & 119.4 & 129.1 \\
25 & 60.7 & 76.5 & 86.4 & 91.9 & 95.6 & 98.5 & 107.3 & 116.0 \\
30 & 55.6 & 70.0 & 79.1 & 84.1 & 87.6 & 90.2 & 98.3 & 106.2 \\
60 & 37.5 & 47.3 & 53.4 & 56.8 & 59.2 & 61.0 & 66.4 & 71.8 \\
360 & 10.7 & 13.5 & 15.3 & 16.2 & 16.9 & 17.4 & 19.0 & 20.5 \\
480 & 8.7 & 11.0 & 12.4 & 13.2 & 13.7 & 14.1 & 15.4 & 16.7 \\
600 & 7.3 & 9.2 & 10.4 & 11.1 & 11.6 & 11.9 & 13.0 & 14.0 \\
720 & 6.3 & 8.0 & 9.0 & 9.6 & 10.0 & 10.3 & 11.2 & 12.1 \\
1440 & 3.7 & 4.7 & 5.3 & 5.6 & 5.9 & 6.0 & 6.6 & 7.1 \\
\hline
\end{tabular}


Table 5. Squares of the deviations between the intensities obtained with the disaggregation and intensities from IDF equation.

\begin{tabular}{ccccccccc}
\hline $\begin{array}{c}\text { Duration } \\
(\mathbf{m i n})\end{array}$ & $\mathbf{9}$ & $\mathbf{9}$ Return period (years) \\
\cline { 2 - 8 } & $\mathbf{2}$ & $\mathbf{5}$ & $\mathbf{1 0}$ & $\mathbf{1 5}$ & $\mathbf{2 0}$ & $\mathbf{2 5}$ & $\mathbf{5 0}$ & $\mathbf{1 0 0}$ \\
\hline 5 & 91.7 & 3.0 & 22.0 & 25.8 & 22.9 & 17.6 & 0.8 & 24.2 \\
10 & 90.8 & 0.7 & 1.6 & 2.0 & 1.2 & 0.3 & 5.9 & 54.4 \\
15 & 45.8 & 0.9 & 8.8 & 10.4 & 9.1 & 6.7 & 0.1 & 13.9 \\
20 & 42.4 & 0.0 & 3.1 & 3.7 & 2.9 & 1.7 & 0.6 & 19.2 \\
25 & 30.0 & 0.3 & 4.3 & 5.0 & 4.3 & 3.0 & 0.0 & 10.6 \\
30 & 19.9 & 1.2 & 6.8 & 7.9 & 7.2 & 5.8 & 0.7 & 3.9 \\
60 & 5.8 & 2.1 & 6.4 & 7.4 & 7.1 & 6.3 & 2.3 & 0.1 \\
360 & 1.5 & 0.0 & 0.0 & 0.0 & 0.0 & 0.0 & 0.2 & 1.0 \\
480 & 1.1 & 0.0 & 0.0 & 0.0 & 0.0 & 0.0 & 0.2 & 0.8 \\
600 & 1.0 & 0.1 & 0.0 & 0.0 & 0.0 & 0.1 & 0.3 & 1.0 \\
720 & 0.9 & 0.2 & 0.1 & 0.1 & 0.1 & 0.2 & 0.4 & 0.1 \\
1440 & 0.5 & 0.2 & 0.1 & 0.1 & 0.2 & 0.2 & 0.4 \\
\hline
\end{tabular}

have adjusted equations for durations of 10 minutes or longer (Pereira et al., 2014). In the design of gutters for rainwater collection on roofs the recommendation from the ABNT (Associação Brasileira de Normas Técnicas, 1989) adopts rain with duration of 5 minutes and 5 years return period. For urban micro drainage it is also common to indicate a return period of 2 years and duration of 5 to 10 minutes. In these rain values the standard error of estimation tends to be higher when the adjustment and equation of heavy rains by the traditional method is performed. The objective function can be altered in order to improve the fit in some branch of the equation, however this entails greater deviations in another segment.

Some authors have adjusted the rainfall equation for the broader range of return period, including values of 500 or 1000 years or up to 10,000 years (Silva Neto et al., 2016). Although making the equation more generalized, this implies a larger standard error of estimation. One way to decrease the estimation error is to adjust more than one equation for different duration intervals. This alternative has the disadvantage of greater difficulty in the adjustment function, it can create discontinuity between the equations and it can also bring problems of use in computer programs that do not have the option for more than one equation. Rodrigues et al. (2008) observed that the general equation presented errors of up to $40 \%$ and thus determined different equations for each considered return period. The authors also report the underestimation of the rain values for duration of 5 minutes. Fiorio et al. (2012) also highlight the alternative for the adoption of two or more equations for the same locality, each encompassing a range of duration and return period. However the authors consider the fact that this procedure can hinder the spatialization of data parameters of intense rainfall equation.

The alternative model proposed for the estimation of rain height and intensity is given by Equations 6 and 7, respectively.

$\mathrm{h}=\left(\frac{\mathrm{t}}{27.9327+3.8346 \mathrm{t}^{0.7924}}\right) \mathrm{P}_{\text {lday }}$

$\mathrm{i}=\left(\frac{60}{27.9327+3.8346 \mathrm{t}^{0.7924}}\right) \mathrm{P}_{\text {dday }}$

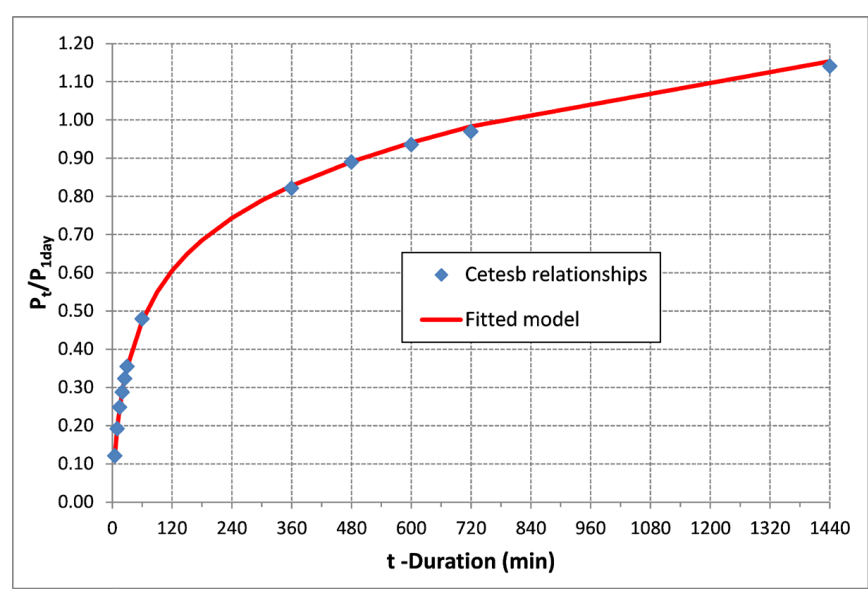

Figure 3. Relationship between rainfall durations given by CETESB (Companhia de Tecnologia de Saneamento Ambiental, 1986) and the fitted model.

Where $\mathrm{h}$ is the height of the rain $(\mathrm{mm})$; $\mathrm{t}$ is the rain duration $\left(0<\mathrm{t} \leq 1440\right.$ minutes); $\mathrm{P}_{1 \text { day }}$ is the maximum rainfall lasting 1 day $(\mathrm{mm}) ; \mathrm{i}$ is the mean maximum rainfall intensity $\left(\mathrm{mm} \mathrm{h}^{-1}\right)$.

Equation 7 provided the sum of squares of the deviations of $33.6\left(\mathrm{~mm} \mathrm{~h}^{-1}\right)^{2}$, implying the standard error of estimate of $0.59 \mathrm{~mm} \mathrm{~h}^{-1}$. It is observed that the proposed equation significantly reduces the deviations between the rain intensity obtained by the disaggregation and rain intensity estimated by the equation (Table 6).

The first term of Equation 6 represents the relationship between the rainfall duration $t$ minutes and the maximum rainfall of one day $\left(\mathrm{Pt} / \mathrm{P}_{1 \text { dax }}\right)$. This relationship is obtained from rainfall disaggregation coefficients from 98 different locations in Brazil (Table 1), and thus has national validity. It is observed (Figure 3) that the adjusted model represents well $\left(\mathrm{R}^{2}=0.9999\right)$ the relationships of Table 1, the maximum differences were $1.4 \%$. This relationships have the advantage of allowing interpolation for duration values that are not included in the Table 1. Another great advantage of this proposed model is that the updating of the intense rainfall equation can be done by changing only the maximum precipitation 
Table 6. Squares of the deviations between the intensities obtained with the disaggregation and intensities from proposed equation.

\begin{tabular}{ccccccccc}
\hline $\begin{array}{c}\text { Duration } \\
(\mathbf{m i n})\end{array}$ & $\mathbf{9}$ & $\mathbf{9}$ Return period (years) \\
\cline { 2 - 8 } & $\mathbf{2}$ & $\mathbf{5}$ & $\mathbf{1 0}$ & $\mathbf{1 5}$ & $\mathbf{2 0}$ & $\mathbf{2 5}$ & $\mathbf{5 0}$ & $\mathbf{1 0 0}$ \\
\hline 5 & 0.2 & 0.3 & 0.3 & 0.4 & 0.4 & 0.5 & 0.5 & 0.6 \\
10 & 1.0 & 1.5 & 1.9 & 2.2 & 2.4 & 2.5 & 3.0 & 3.5 \\
15 & 0.1 & 0.1 & 0.2 & 0.2 & 0.2 & 0.2 & 0.3 & 0.3 \\
20 & 0.3 & 0.5 & 0.7 & 0.7 & 0.8 & 0.9 & 1.0 & 1.2 \\
25 & 0.1 & 0.2 & 0.3 & 0.3 & 0.3 & 0.4 & 0.4 & 0.5 \\
30 & 0.0 & 0.0 & 0.0 & 0.0 & 0.0 & 0.0 & 0.0 & 0.0 \\
60 & 0.1 & 0.1 & 0.2 & 0.2 & 0.2 & 0.2 & 0.2 & 0.3 \\
360 & 0.0 & 0.0 & 0.0 & 0.0 & 0.0 & 0.0 & 0.0 & 0.0 \\
480 & 0.0 & 0.0 & 0.0 & 0.0 & 0.0 & 0.0 & 0.0 & 0.0 \\
600 & 0.0 & 0.0 & 0.0 & 0.0 & 0.0 & 0.0 & 0.0 & 0.0 \\
720 & 0.0 & 0.0 & 0.0 & 0.0 & 0.0 & 0.0 & 0.0 & 0.0 \\
1440 & 0.0 & 0.0 & 0.0 & 0.0 & 0.0 & 0.0 & 0.0 & 0.0 \\
\hline
\end{tabular}

Table 7. Values of logarithmic regression adjustment coefficients $\mathrm{d}$ and e for various distributions.

\begin{tabular}{lccc}
\hline \multicolumn{1}{c}{ Probability } & \multicolumn{3}{c}{ Coefficients of regression } \\
\cline { 2 - 4 } \multicolumn{1}{c}{ Distribution ${ }^{1}$} & d & e & $\mathbf{R}^{\mathbf{2}}$ \\
\hline LN2-MM & 36.62 & 52.7 & 0.9995 \\
LN2-ML & 15.31 & 73.2 & 0.9943 \\
LN2-MML & 16.42 & 72.3 & 0.9951 \\
LN3-MM & 14.99 & 74.7 & 0.9918 \\
LN3-ML & 24.70 & 52.2 & 0.9981 \\
LN3-MML & 18.06 & 69.0 & 0.9981 \\
PIII-MM & 16.94 & 71.6 & 0.9946 \\
PIII-ML & 14.40 & 74.9 & 0.9911 \\
PIII-MML & 16.94 & 71.6 & 0,9947 \\
LPIII-MM & 27.18 & 65.6 & 0,9996 \\
LPIII-ML & 16.94 & 71.6 & 0.9947 \\
LPIII-MML & 16.96 & 71.2 & 0.9966 \\
Gb-MM & 17.96 & 68.2 & 0.9989 \\
Gb-ML & 17.85 & 68.0 & 0.9988 \\
Gb-MML & 18.76 & 67.6 & 0.9989 \\
Gb-Ch & 20.04 & 67.3 & 0.9988 \\
GEV-MM & 14.62 & 75.8 & 0.9867 \\
GEV-MML & 18.07 & 69.1 & 0.9979 \\
\hline
\end{tabular}

${ }^{1}$ Log-Normal with two parameters (LN2); Log-Normal with three parameters (LN3); Pearson type III (PIII); Log Pearson type III (LPIII) Gumbel distribution (Gb); Generalizes Distribution of Extreme Values (GEV); Method of moments (MM); Maximum likelihood method of (ML); Method of L-moments (MML);Chow method (Ch).

value of one day. For this procedure there is an extensive literature and it does not require more complex calculations.

The proposed method also has the advantage that P1dia values can be easily specialized, and with much more reasonable interpretation than the spatialization of the coefficients of the IDF equation as discussed in several articles on the spatialization methods and errors resulting from the estimates of equation IDF (Mello et al., 2003; Senna et al., 2010; Rabelo et al., 2017). With the proposed model and the spatialization of the values of P1day it is expected that the resulting errors are much lower.

In the design of terraces and erosion control drainage channels it is recommended to use the intensity of rainfall with return period of 10 years (Lombardi Neto et al., 1991; De Maria et al., 2016). The duration varies according to the type

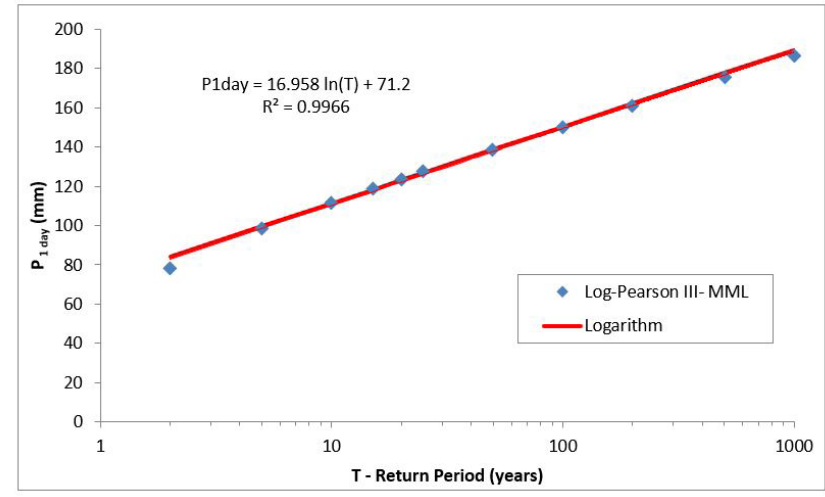

Figure 4. Logarithmic regression between maximum one-day rainfall estimated by Log-Pearson type III with parameters estimated by de L-moments method (MML) and return period.

of terrace or channel and the method of calculation. For terraces in gradient it is recommended to use the duration of 15 minutes, as for terraces in level it is recommended the rain with duration of 24 hours (Lombardi Neto \& Drugowich, 1994; ASAE Standards, 2012; De Maria et al., 2016). Thus, the proposed equation is of great practical application, since from the daily rainfall map with a 10-year return period one can obtain the intensity of the project rainfall for a given location.

The intensity equation proposed by Equation 7 relates intensity and duration. A more generalized equation can be obtained, including the frequency with the substitution of the term $\mathrm{P}_{1 \text { day }}$ by an expression that includes the return period, being as follows:

$\mathrm{h}=\left(\frac{\mathrm{t}}{27.9327+3.834 \mathrm{t}^{0.7924}}\right)(\mathrm{d}+\ln (\mathrm{T})+)$

where: $h$ is the height of the rain with duration $t$ minutes and period of return $\mathrm{T}$ years $(\mathrm{mm})$; $\mathrm{t}$ is the rain duration $(0<\mathrm{t} \leq 1440$ minutes); $\mathrm{T}$ is the return period (years); $\mathrm{d}$, e are coefficients that must be adjusted by logarithmic regression of the maximum daily rainfall values and the return period.

For the various distributions tested in this work, the coefficients d, e (Table 7) were adjusted. It is observed that for most of the distributions the adjustment was considered very good by the logarithmic model, with $\mathrm{R}^{2}$ higher than 0.99 . 


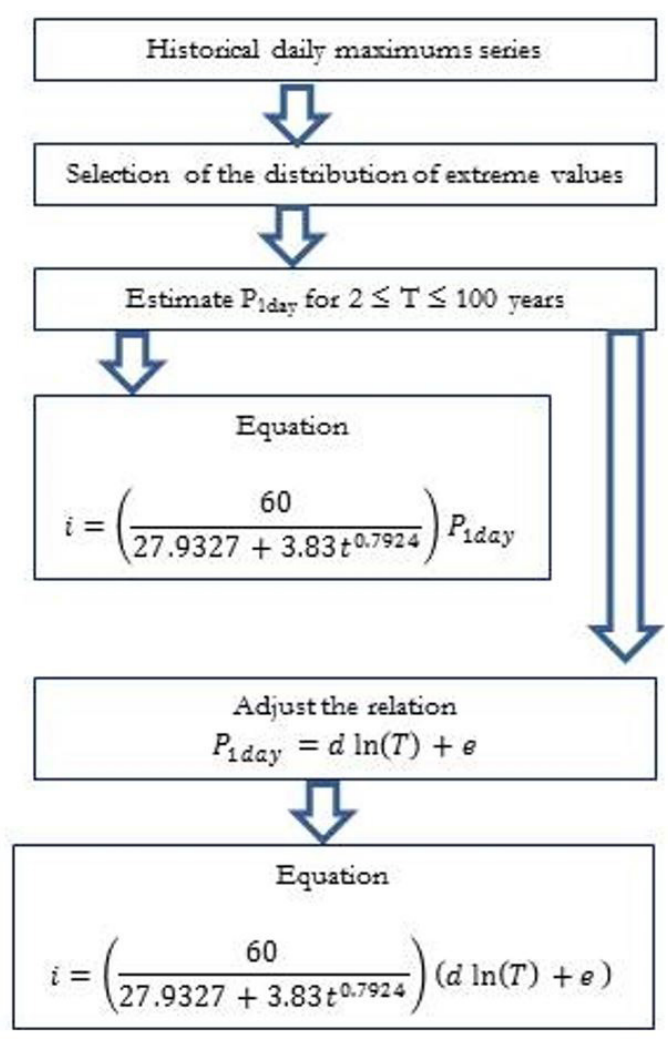

Figure 5. Schematization of the algorithm that generates the proposed equations by daily rainfall disaggregation.

For the GEV-MM distribution, the logarithmic model showed larger deviations, with $\mathrm{R}^{2}$ of 0.9867 . For the LPIII-MML distribution the logarithm model presented $\mathrm{R}^{2}$ of 0.9966 , and the quality of the adjustment can be seen in Figure 4.

Thus the equation for the estimation of rain height with duration $\mathrm{t}$ minutes and $\mathrm{T}$ period of return is given by:

$\mathrm{h}=\left(\frac{\mathrm{t}}{27.9327+3.8346 \mathrm{t}^{0.7924}}\right)(16.958 \mathrm{Ln}(\mathrm{T})+71.2)$

Where: $\mathrm{t}$ is the rain duration $((0<\mathrm{t} \leq 1440$ minutes $), \mathrm{T}$ is the return period (2 to 1000 years).

The equation that relates intensity, durations and frequency is expressed by Equation 10, where the sum of the squares of the deviations $\mathrm{S}=129.4\left(\mathrm{~mm} \mathrm{~h}^{-1}\right)^{2}$, with a standard error of estimation of $1.16 \mathrm{~mm} \mathrm{~h}^{-1}$. Although the standard error obtained with Equation 9 is somewhat higher than that of Equation 7, it is still much lower than that obtained with the traditional IDF equation.

$\mathrm{i}=\left(\frac{60}{27.9327+3.8346 \mathrm{t}^{0.7924}}\right)(16.958 \ln (\mathrm{T})+71.2)$

Where: $\mathrm{i}$ is rainfall intensity $\left(\mathrm{mm} \mathrm{h}^{-1}\right)$; $\mathrm{t}$ is the rain duration $(0<\mathrm{t} \leq 1440$ minutes); $\mathrm{T}$ is the return period ( 2 to 1000 years).

This model allows us to use the equation for a broad range of return period without increasing the standard error of estimation, as observed in the adjustment of the traditional IDF equation.

Figure 5 shows the algorithm for obtaining the intense rainfall equation in the proposed methodology. This method does not require the equations of intense rainfall adjustment and when applied based on the disaggregation of daily rainfall, it is possible to obtain the intense rainfall equation with the least computational effort and with better estimates accuracy

\section{CONCLUSION}

Based on the results obtained it can be concluded that:

1) Although the adhesion tests indicate that more than one probability distribution can be used for the estimation of maximum daily rainfall, one should carefully analyze the best distribution to be used;

2) The model of the proposed equation for the estimation of the rain intensity from the disaggregation of the maximum daily rainfall is given by:

$\mathrm{i}=\left(\frac{60}{27.9327+3.8346 \mathrm{t}^{0.7924}}\right) \mathrm{P}_{\text {lday }}$

where $\mathrm{i}$ is the rainfall intensity $\left(\mathrm{mm} \mathrm{h}^{-1}\right) ; \mathrm{t}=$ rain duration $\left(0<\mathrm{t} \leq 1440\right.$ minutes); $\mathrm{P}_{1 \mathrm{day}}=$ maximum rainfall lasting 1 day $(\mathrm{mm})$;

3) The proposed model has the advantage of allowing updating only with the update of the estimation of the maximum rainfall with duration of 1 day and presents the lowest standard error of estimation when compared to the traditional IDF equations;

4) The model that includes the frequency can be expressed by:

$\mathrm{i}=\left(\frac{60}{27.9327+3.8346 \mathrm{t}^{0.7924}}\right)(16.958 \ln (\mathrm{T})+71.2)$

where $\mathrm{i}$ is the rainfall intensity $\left(\mathrm{mm} \mathrm{h}^{-1}\right)$; $\mathrm{t}$ is the rain duration $(0<\mathrm{t} \leq 1440$ minutes); $\mathrm{T}$ is the return period ( 2 to 1000 years);

5) The proposed equations are indicated as alternatives to the IDF equations traditionally adjusted by disaggregation of maximum 1-day rains.

\section{REFERENCES}

Almeida, K. N., Reis, J. A. T., \& Mendonça, A. S. F. (2015). Avaliação do desempenho dos métodos expeditos de determinação de equações de chuvas intensas. Revista Brasileira de Ciências Ambientais, 35, 63-77.

Almeida, K. N., Reis, J. A. T., \& Mendonça, A. S. F. (2017). Emprego dos métodos expeditos de Chow Gumbel e Bell para formulação de equações de chuvas intensas - uma avaliação de desempenho. Revista Ambiente \& Água, 12(2), 203-2014. http:// dx.doi.org/10.4136/ambi-agua.2001.

Aragão, R., Santana, G. R., Costa, C. E. F. F., Cruz, M. A. S., Figueiredo, E. E., \& Srinivasan, V. (2013). Chuvas intensas para o Estado de Sergipe com base em dados desagregados de chuva diária. Revista Brasileira de Engenharia Agricola e Ambiental, 17(3), 243-252. http://dx.doi.org/10.1590/S1415-43662013000300001. 
ASAE Standards. (2012). S268.5 JAN2012. Design, layout, construction and maintenance of terrace systems. St. Joseph, Michigan: American Society of Agricultural Engineers.

Associação Brasileira de Normas Técnicas - ABNT. (1989). NBR 10844: Instalações prediais de águas pluviais. Rio de Janeiro: ABNT.

Back, Á. J. (2013). Chuvas intensas e chuva para dimensionamento de estorturaras de drenagem ara o Estado de Santa Catarina (Com programa HidroCbuSC para cálculos (193 p.). Florianópolis: Epagri.

Back, Á. J., Henn, A., \& Oliveira, J. L. R. (2011). Heavy rainfall equations for Santa Catarina, Brazil. Revista Brasileira de Ciência do Solo, 35(6), 2127-2134. http://dx.doi.org/10.1590/S010006832011000600027.

Basso, R. E., Allasia, D. G., Tassi, R., \& Pickbrenner, K. (2016). Revisão das isozonas de chuvas intensas do Brasil. Engenharia Sanitária e Ambiental, 27(4), 635-641. http:/ / dx.doi.org/10.1590/ S1413-41522016133691.

Berne, A., Delrieu, G., Creutin, J. D., \& Obled, C. (2004). Temporal an spatial resolution of rainfall measurements required for urban hydrology. Journal of Hydrology (Amsterdam), 299(3-4), 166-179. http://dx.doi.org/10.1016/S0022-1694(04)00363-4.

Bielenki Júnior, C., Barbassa, A. P., Miranda, R. B., \& Mauad, F. F. (2016). Determinação de curva intensidade-duração-frequência por meio do emprego do método paramétrico de ajustamento de observações. Revista Brasileira de Climatologia, 19, 146-167.

Braga, R. N. S., Hora, M. A. G. M., Lyra, G. B., \& Nascentes, A. L. (2018). Determinação e interpolação dos coeficientes das equações de chuvas intensas para cidade do Rio de Janeiro. Revista Ambiente \& Água, 13(1), E2076. http://dx.doi.org/10.4136/ambi-agua.2076.

Caleira, T. L., Beskow, S., Mello, C. R., Vargas, M. M., Guedes, H. A. S., \& Faria, L. C. (2015). Daily rainfall disaggregation: an analysis for the Rio Grande do Sul State. Revista Scientia Agraria, 16(3), 1-21.

Campos, A. R., Santos, G. G., Silva, J. B. L., Irene Filho, J., \& Loura, D. S. (2014). Equações de intensidade-duração-frequência de chuvas para o estado do Piauí. Ciência Agronômica, 45(3), 488498. http://dx.doi.org/10.1590/S1806-66902014000300008.

Cecílio, R. A., Xavier, A. C., Pruski, F. F., Hollanda, M. P., \& Pezzopane, J. E. M. (2009). Avaliação de interpoladores para os parâmetros das equações de chuvas intensas no Espírito Santo. Revista Ambiente \& Água, 4(3), 82-92. http://dx.doi.org/10.4136/ ambi-agua.104.

Cheng, L., \& Aghakouchak, A. (2014). Nonstationary precipitation intensity-duration-frequency curves for infrastructure design in a changing climate. Scientific Reports, 4, 7093, 1-6. https://doi. org/10.1038/srep07093.
Coelho Filho, J. A. P., Melo, D. C. R., \& Araújo, M. L. M. (2017). Estudo de chuvas intensas para a cidade de Goiânia/GO por meio da modelação de eventos máximos anuais pela aplicação das distribuições de Gumbel e Generalizada de Valores Extremos. Ambiência, 13(1), 75-88.

Companhia de Tecnologia de Saneamento Ambiental - CETESB. (1986). Drenagem urbana: manual de projetos (466 p.). São Paulo: DAEE/CETESB.

Costa, C. E. A. S., Blanco, C., \& Oliveira-Júnior, J. F. (2019). IDF curves for future climate scenarios in a locality of the Tapajós, Basin, Amazon, Brazil. Journal of Water and Climate Change, 10, 1-11.

Damé, R. C. F., Teixeira, C. F. A., \& Terra, V. S. S. (2008). Comparação de diferentes metodologias para estimativa de curvas intensidadeduração-frequência para Pelotas- RS. Engenharia Agrícola, 28(2), 245-255. http://dx.doi.org/10.1590/S0100-69162008000200005.

De Maria, I. C., Drugowich, M. I., \& Bortoletti, J. O., Vitti, A. C., Rossetto, R., Fontes, J. L., Tcatchenco, J., \& Margatho, S. F. (2016). Recomendações gerais para a conservação do solo na cultura da cana-de-açúcar. Campinas: Instituto Agronômico.

Fietz, C. R., Comunello, E., Cremon, C., Dallacort, R., \& Pereira, S. B. (2011). Chuvas intensas no Estado de mato Grosso (117 p.). Brasília: Embrapa Agropecuária Oeste.

Fiorio, P. R., Duarte, S. N., Rodrigues, G. O., Miranda, J. H., \& Cooke, R. A. (2012). Comparação de equações de chuvas intensas para localidades do estado de São Paulo. Engenharia Agrícola, 32(6), 1080-1088. http://dx.doi.org/10.1590/S0100-69162012000600009.

Garcia, S. S., Amorim, R. S. S., Couto, E. G., \& Stopa, W. H. (2011). Determinação da equação intensidade-duração-frequência para três estações meteorológicas do Estado de Mato Grosso. R. Bras. Engenharia Agricola e Ambiental, 15(6), 575-581. http://dx.doi. org/10.1590/S1415-43662011000600006.

Griebeler, N. P., Pruski, F. F., Teixeira, A. F., \& Oliveira, L. F. C. (2005). Software para o planejamento e a racionalização de sistemas de terraceamento em nível. Engenharia Agrícola, 25, 841-851. http:// dx.doi.org/10.1590/S0100-69162005000300031

Helfer, A. L., Dornelles, F., \& Goldenfum, J. A. (2017). Implications of discontinuous IDF equations in generation of runoff hydrographs. Case study: IDF-Porto Alegre ( $8^{\circ}$ DISME). Revista Brasileia de Recursos Hidricos, 22(e52), 1-9. http://dx.doi.org/10.1590/23180331.0217170004 .

Hosking, J. R. M., \& Wallis, J. R. (1997). Regional frequency analysis: an approach based on L-moments $(224$ p.). Cambridge: Cambridge University Press. http://dx.doi.org/10.1017/CBO9780511529443.

Kite, G. H. (1977). Frequency and risk analyses in bydrology (224 p.). Fort Collins: Water Resources Publication. 
Liew, S. C., Raghavan, S. V., \& Liong, S. (2014). How to construct future IDF curves, under changing climate, for sites with scarce rainfall records? Hydrological Processes, 28(8), 3276-3287. http:// dx.doi.org/10.1002/hyp.9839.

Lombardi Neto, F., \& Drugowich, M. I. (1994). Manual técnico de manejo e conservação do solo e água (Vol. 38-42). Campinas: CATI.

Lombardi Neto, F., Bellinazzi Júnior, R., Lepsch, I. F., Oliveira, J. B., Bertolini, D., Galeti, P. A., \& Drugowich, M. I. (1991). Terraceamento agrícola (Boletim Técnico, Vol. 206). Campinas: Coordenadoria da Assistência Técnica Integral.

Martins, D., Kruk, N. S., \& Magni, N. L. G., \& Queiroz, P. I. B. (2017). Comparação de duas metodologias de obtenção da equação de chuvas intensas para a cidade de Caraguatatuba (SP). Revista DAE, 34-49.

Mello, C. R., Lima, J. M., Silva, A. M., Mello, J. M., \& Oliveira, M. S. (2003). Krigagem e inverso do quadrado da distância para interpolação dos parâmetros da equação de chuvas intensas. Revista Brasileira de Ciência do Solo, 27(5), 925-933. http://dx.doi. org/10.1590/S0100-06832003000500017.

Miranda, A. C. R., Silva, D. P., Mello, E. L., \& Pruski, F. F. (2012). Assessment of efficiency and adequacy of retention terraces. Revista Brasileira de Ciência do Solo, 36(2), 577-586. http://dx.doi. org/10.1590/S0100-06832012000200027.

Naghettini, M., \& Pinto, E. J. A. (2007). Hidrologia estatística (552 p.). Belo Horizonte: CPRM.

Oliveira, L. F. C., Antonini, J. C. A., \& Griebeler, A. N. (2008). Estimativas de chuvas intensas para o estado de Goiás. Engenharia Agricola, 28(1), 22-33. http://dx.doi.org/10.1590/S010069162008000100003.

Oliveira, L. F. C., Cortês, F. C., Wehr, T. R., Borges, L. B., Sarmento, P. H. L., \& Griebeler, N. P. (2005). Intensidade-duração-frequência de chuvas intensas para localidades no Estado de Goiás e Distrito Federal. Pesquisa Agropecuária Tropical, 35(1), 13-18.

Ottero, C. R., Chargel, L. T., \& Hora, M. A. G. M. (2018). Análise de frequência dos dados pluviométricos observados em 2011 a 2013 na região Serrano do Rio de Janeiro. Revista Brasileira de Meteorologia, 33(1), 131-139. http://dx.doi.org/10.1590/0102-7786331007.

Pereira, D. C., Duarte, L. R., \& Sarmento, A. P. (2017). Determinação da curva de intensidade, duração e frequência do município de Ipameri - Goiás. Revista Eletrônica de Engenharia Civil, 3(2), 233-245. http://dx.doi.org/10.5216/reec.v13i2.43330.

Pereira, S. B., Nóia, C. P. Z., Almeida, R. A., \& Coelho, C. D. (2014). Method adjustment and equation set of maximum rainfall intensity, duration and frequency in the Mato Grosso do Sul state. Engenharia Agricola, 34(4), 716-726. http://dx.doi.org/10.1590/ S0100-69162014000400011.
Pérez-Zanón, N., Casas-Castillo, M. C., Rodriguez-Sola, R., Pena, J. C., Rius, A., Sole, J. G., \& Redano, A. (2016). Analysis of extreme rainfall in the Ebre Observatory (Spain). Theoretical and Applied Climatology, 124(3-4), 935-944. http://dx.doi.org/10.1007/ s00704-015-1476-0.

Pompeu, C. A. (1992). Equação de chuvas intensas para Florianópolis. Florianópolis: Departamento de Engenharia Sanitária e Ambiental, Universidade Federal de Santa Catarina.

Pruski, F. F., Silva, D. D., Teixeira, A. F., Cecílio, R. A., Silva, J. M. A., \& Griebeler, N. P. (2006). Hidros: dimensionamento de sistemas bidroagrícolas (259 p.). Viçosa: UFV.

Quadros, L. E., Queiroz, M. M. F., \& Boas, M. A. V. (2011). Distribuição de frequência de temporal de chuvas intensas. Acta Scientiarum. Agronomy, 33(3), 401-410. http://dx.doi.org/10.4025/ actasciagron.v33i3.6021.

Rabelo, A. E. C. G. C., Ribas, L. V. S., Coutinho, A. P., Ribeiro Neto, A., \& Antonino, A. C. D. (2017). Espacialização dos parâmetros de equações de chuvas intensas para a Região Metropolitana do Recife. Revista Brasileira de Geografia Física, 11(4), 1542-1554. http:/ / dx.doi.org/10.26848/rbgf.v11.4.p1542-1554.

Rangel, E. M., \& Hartwig, M. P. (2017). Análise das curvas de intensidade-duração-frequência para a cidade de Pelotas através de uma função de desagregação. Revista Thema, 14(2), 63-77. http:/ / dx.doi.org/10.15536/thema.14.2017.63-77.353.

Robaina, A. D. (1996). Modelo para geração de chuvas intensas no Rio Grande do Sul. Revista Brasileira de Agrometeorologia, 4(2), 95-98.

Rodrigues, J. O., Andrade, E. M., Oliveira, T. S., \& Lobato, A. O. (2008). Equações de Intensidade-duração-frequência de chuvas para as localidades de Fortaleza e Pentecoste, Ceará. Scientia Agraria, 9(4), 511-519. http://dx.doi.org/10.5380/rsa.v9i4.12505.

Santos, R. A. (2015). Cálculo da chuva intensa pelo método das Isozonas para cidades do estado da Paraíba. Revista Eletrônica em Gestão, Educação e Tecnologia Ambiental, 19(2), 1334-1343.

Senna, R. S., Xavier, A. C., Lima, J. S. S., \& Cecílio, R. A. (2010). Metodologias para estimativa dos parâmetros da equação de chuvas intensas no estado do Espírito Santo. Engenharia na Agricultura, 18(6), 496-503. http://dx.doi.org/10.13083/reveng.v18i6.85.

Silva Neto, V. L., Viola, M. R. V., Rego, P. L., Oliveira, A. L., \& Silva, L. L. (2016). Relação Intensidade-duração-frequência (IDF) para precipitação Extrema em Guaraí-TO. Enciclopédia Biosfera, 13(23), 1146-1154. http://dx.doi.org/10.18677/Enciclopedia_ Biosfera_2016_099.

Silva, B. M., Montenegro, S. M. G. L., Silva, F. B., \& Araújo Filho, P. F. (2012). Chuvas intensas em localidades do estado de Pernambuco. Revista Brasileira de Recursos Hídricos, 17(3), 135-147. http://dx.doi.org/10.21168/rbrh.v17n3.p135-147. 
Silva, C. B., \& Oliveira, L. F. C. (2017). Relação intensidadeduração-frequência de chuvas extremas na região Nordeste do Brasil. Revista Brasileira de Climatologia, 20, 267-283.

Silva, R. S., \& Araújo, G. R. S. (2013). Algoritmo para determinação da equação de chuvas intensas. Revista Brasileira de Geografia Física, 6(5), 1371-1383. http://dx.doi.org/10.26848/rbgf.v6i5.233110.

Silveira, A. L. L. (2016). Equações cumulativas sequenciais do hietograma do método de Chicago. Revista Brasileira de Recursos Hídricos, 21(3), 646-651.

Sobrinho, V. F., Rodrigues, J. O., Mendonça, L. A. R., Andrade, E. M., \& Tavares, P. R. L. (2014). Desenvolvimento de equações Intensidade-Duração-Frequência sem dados pluviográficos em regiões semiáridas. Revista Brasileira de Engenharia Agrícola e Ambiental, 18(7), 727-734. http://dx.doi.org/10.1590/S141543662014000700009.

Srivastav, R. K., Schardong, A., \& Simonovic, S. P. (2014). Equidistance quantile matching method for updating IDF curves under climate change. Water Resources Management, 28(9), 2539-2562. http://dx.doi.org/10.1007/s11269-014-0626-y.

Srivastav, R. K., Schardong, A., \& Simonovic, S. P. (2016). Computerized tool for the development of intensity-durations-frequency curves under a changing climate: water resources resport, technical manual (Vol. 14, 58 p.). London: Western University.

Svensson, C., Clarke, R. T., \& Jones, D. A. (2007). An experimental comparison of methods for estimating rainfall intensity-durationfrequency relations from fragmentary records. Journal of Hydrology (Amsterdam), 341(1-2), 79-89. http://dx.doi.org/10.1016/j. jhydrol.2007.05.002.

Tucci, C. E. M. (2013). Hidrologia: ciência e aplicaşão (4. ed., 943 p.). Porto Alegre: UFRGS.

Xavier, A. C., Cecílio, R. A., Pruski, F. F., \& Lima, J. S. S. (2014). Methodology for spatialization of intense rainfall equation parameters. Engenharia Agricola, 34(3), 485-495. http://dx.doi. org/10.1590/S0100-69162014000300012.

Yue, S., Pilon, P., \& Cavadias, G. (2002). Power of the MannKendall and Spearman's rho tests for detecting monotonic trends in hydrological series. Journal of Hydrology (Amsterdam), 259(1-4), 254-271. http://dx.doi.org/10.1016/S0022-1694(01)00594-7.

\section{Author contribution}

Álvaro José Back: Responsible for the paper. 